\title{
Investigation of Internal Erosion Susceptibility of Core Soil from Three Dams
}

\author{
Ahmed Jalil ${ }^{1,2}$, Ahmed Benamar ${ }^{1, *}$, Mohamed Ebn Touhami ${ }^{2}$ \\ 1. LOMC UMR 6294, CNRS-University of Le Havre Normandie, Department of civil Engineering, 53 rue de \\ Prony 76600 Le Havre, France \\ 2. Laboratory of Materials and Environment Engineering, University of Ibn Tofail, B.P 242, Kenitra, Morocco \\ E-mail: ahmed.jalil87@gmail.com; ahmed.benamar@univ-lehavre.fr; M.ebntouhami@gmail.com
}

Received: 16 December 2020; Accepted: 21 January 2021; Available online: 25 February 2021

\begin{abstract}
Laboratory tests on internal erosion of cohesionless soils are often performed on cells submitted to a controlled seepage. The cell dimension depends on the grain size of tested soil and must meet the geometric and hydraulic scale requirements as regards to the modeled process. Three specimens collected from different zoned dams in Morocco were characterized for their geotechnical properties and dispersion sensitivity, and then submitted in two different cells to internal erosion (Hole Erosion Test) under controlled seepage. The erosion kinetics was measured, and soil classification was assessed as regards to the useful engineering guidelines. The results showed that specimen dimensions can affect the erosion parameters which are quite different from a cell to another. Even though the derived erosion coefficient values are different from the two testing cells, the classification of the three soils regarding the susceptibility to erosion, using engineering guidelines, indicated that the tested soils fall overall in neighboring erosion classifications. However, the soil involving the lower clay content provided the greatest resistance against internal erosion.
\end{abstract}

Keywords: Dam; Hole erosion; Dispersion; Core soil; Vulnerability.

\section{Introduction}

Internal erosion is involved by the detachment and transport of fine particles in the earthen structure under the effect of a strong seepage through its structure or its foundations. These flows, often local, can move and washout the soil particles until the formation of a major preferential pathway where the speed of the flow increases gradually. If it was not detected in time or poorly controlled, erosion process can induce a washout of a considerable amount of material in the work, or create hydraulic or mechanical instabilities in the structure of the work until partial or total failure. The origin of these unfavorable seepages and subsequently internal erosion can be linked to the construction (lack of compaction, poor contact between two adjacent layers of the same nature or not ...) or to a pathological (holes that can be created for different reasons such as by burrowing animals, roots rotten trees, cracks following the structure settlement). These processes can also accelerate during an exceptional event (earthquake, fast filling of the reservoir). Once the fine particles are removed from an internally unstable soil by seepage forces (suffusion), the hydraulic and mechanical behaviors change accordingly and lead to a reduction of soil shear strength, the onset of settlements and soil cracking [1, 2].

However, initiation of erosion is difficult to detect since it is not visible outside the earthen structure and does not cause a leakage rate or a significant settlement. When one of the two indicators is detected, the consequences are already dramatic because it is often too late to intervene and ensure the sustainability of the structure in operation. Haouzi et al. [3] have shown, through a testing procedure, the possibility of experimentally quantifying the hydraulic gradient at which erosion begins, and the possibility of evaluating the mass or quantity of the particles eroded under controlled hydraulic conditions. As they showed through the analysis of the soil GSD (grain size distribution) curve following erosion, the quantity of fine particles which erode at the top is greater than those which erode at the bottom of the tested samples.

Fell et al. [4] have shown, that in many dams which suffer poor internal erosion and are constructed mainly of earth fill, the time for potential development of piping is short, and for these dams continuous monitoring of seepage or surveillance would be needed to detect the piping in time to give warning of possible failure, and to give time to attempt intervention to prevent the failure. Sadaghiani et al. [5] concluded that the degree of suffusion of a soil is closely related to the local segregation of the particles inside the soil body, and the complexity of effects of particle arrangement on the degree of erodibility. The extent of suffusion was dependent on the homogeneity of 
the soil. The suffusion can occur even if a low hydraulic gradient is applied [2], the erosion process is influenced by the rate of the hydraulic gradient increase [6].

In addition to the erosion initiation phenomena by the mechanical effects of water soil (internal erosion), there is also another erosion mechanism related to the soil nature, and that is dispersion, where the effect of electrochemical forces keeps particles away from one another in the fluid. The mechanism is subject to opposing forces that generate the double layer extension [7]. The mechanisms responsible for the transfer of colloidal substance originally flocculated in a dispersed form can be of a physical, chemical, or physicochemical nature. The process of soil dispersion is known as the suspension of individual colloidal particles of clays in water without movement. The potential of a soil to disperse is very widely interpreted in the literature as sensitivity to erosion $[8,9]$. Suspending the particles, in other words reducing the size of the agglomerates of clay particles can facilitate their mobility or clog a preferential flow path. The soils dispersion is closely linked to the nature of the clays they contain and their reactivity in presence of water.

In hydraulic structures, internal erosion develops through four stages: initiation, continuation, progression, and breach failure. Concerning pipe erosion, some authors have studied the role of compaction conditions on erosion characteristics (erosion kinetics and critical shear stress). It was reported in literature $[10,11]$ that high initial water content (above the optimal value) causes a more severe erosion. Compaction conditions can affect the internal erosion characteristics of soils. The increase in the initial dry density induces a decrease in the erosion coefficient $[10,11]$ as well as an increase in the critical stress [12]. Wahl [13] has also shown that along the compaction curve, resistance to erosion is optimal for the values of the dry density and water content corresponding to the optimum of compaction. The influence of clay content has been characterized by several authors $[12,14,15]$. Using sandclay mixtures, they showed that increasing the percentage of clay induces an increase in critical stress and a decrease in the coefficient of erosion [12-14, 15]. Mehenni et al. [16] have shown that the soils treatment can improve their resistance to erosion. So, the treatment with clay products can decrease the coefficient of erosion and this reduction depends on the clay content and nature.

This research aims to investigate the vulnerability to internal erosion of core soils collected from earthen dams in Morocco. This is besides the fact that mostly the embankment dams are only exposed to low hydraulic heads and remain largely unsaturated [17]. After the identification of each dam characteristics, the soil specimens collected from the different dam's core were analyzed. Then, the soil susceptibility to internal erosion was assessed by conducting two kinds of laboratory tests: Crumb Test and Hole Erosion Test using two different cell dimensions.

\section{Materials and methods}

\subsection{Dams description}

The site of Koudiat El Garn and Mazer dams is in Settat-Berrechid region (Morocco) in Oued Bouregreg (Fig. 1). In 2012, Koudiat El Garn dam was put into operation and Mazer dam started operating on 2011. The site of Moulay Boucheta dam is located about $12 \mathrm{~km}$ northwest of Chefchaouen (Morocco) area in Oued Moulay Boucheta (Fig. 1) and this dam was put into operation in 2014. These three zoned dams whose role is to protect against flooding and to ensure irrigation of the lands located downstream, include mainly in their structure a central core, a filter, upstream and downstream embankments, and protections (Fig. 2).
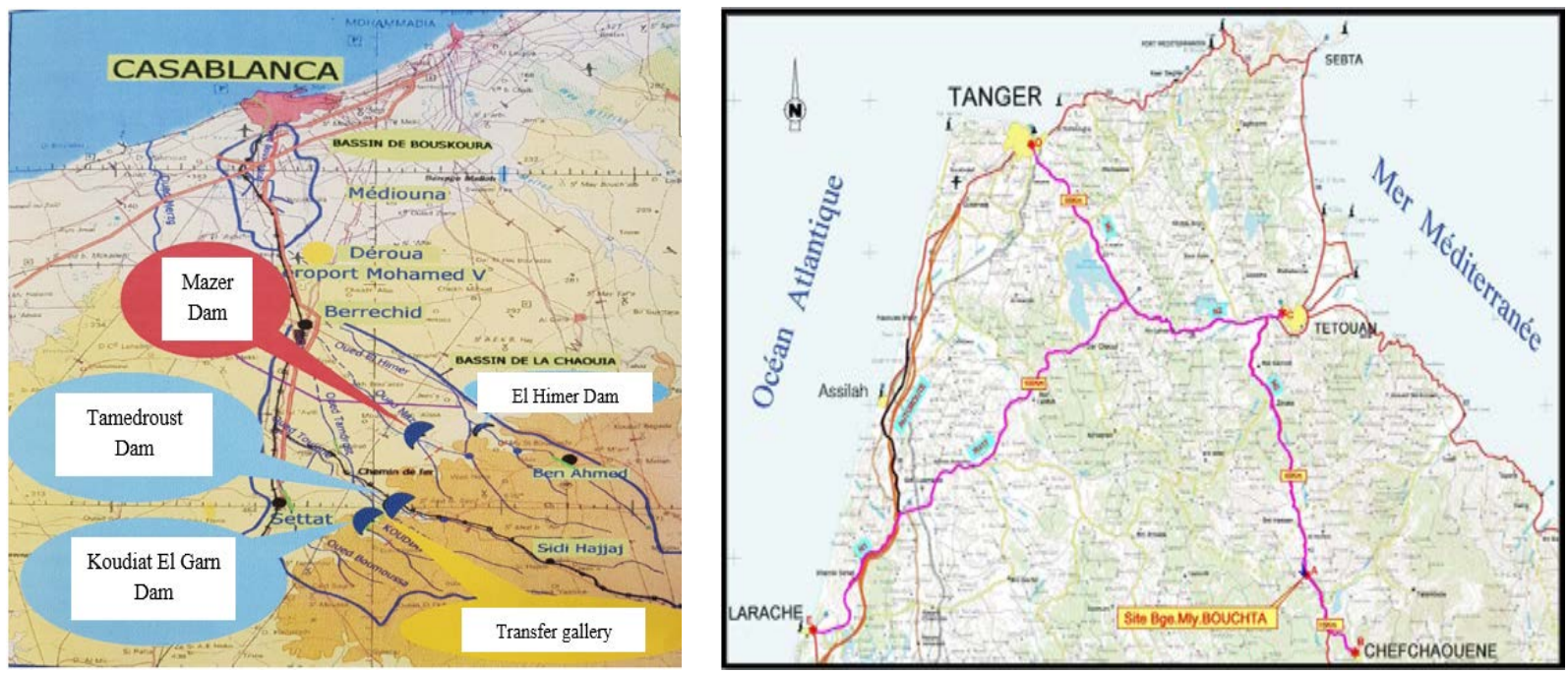

Fig. 1. A map depicting the location of (a) Kouadiat El Garn and Mazer dams, (b) Moulay Boucheta dam 
a)

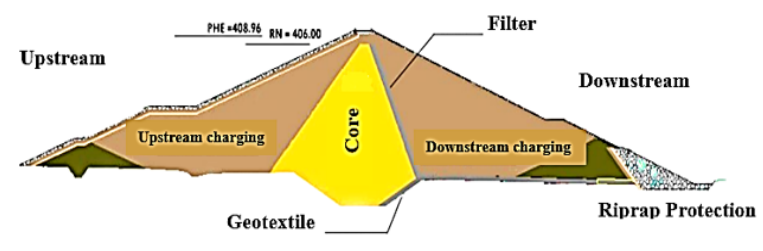

c)

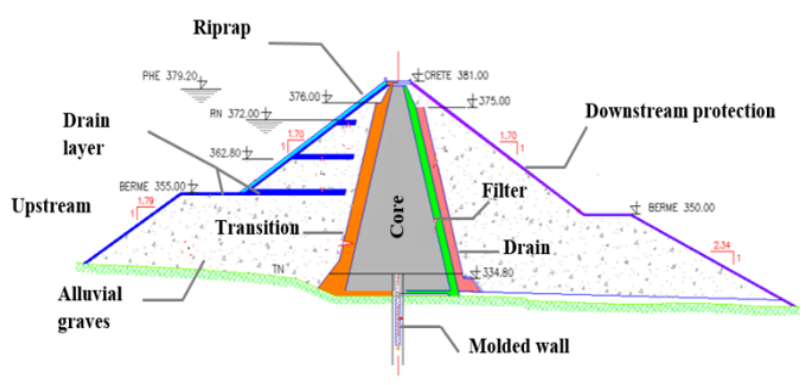

b)

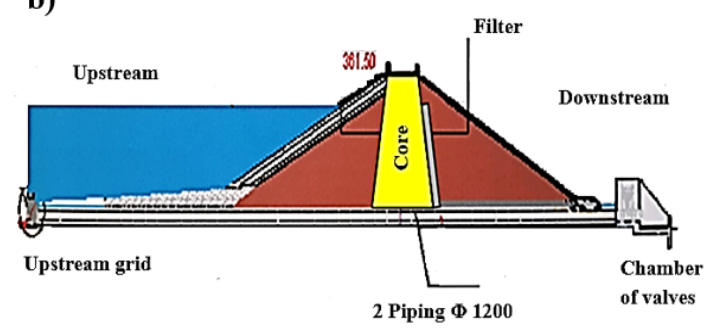

Fig. 2. Cross-section views of the dykes of (a) Koudiat El Garn dam, (b) Mazer dam, and (c) Moulay Boucheta dam

\subsection{Materials}

The soils from collected core samples of three dams provide different characteristics (Table 1), indicating that Moulay Boucheta dam core involves the most important plastic soil, while the two other core soils are of the quite similar plasticity. The used soil classification (ASTM D2487- 17, 2017) [18] shows that the two core soils from Mazer and Moulay Boucheta dams are fat clay material while the third core (from Koudiat El Garn dam) involves a lean clay material.

The core materials tested came from borrowings located in the reservoir areas from each of the three dams. The preparation and the homogenization of materials as regard to water content, and compaction requirements were achieved targeting the same conditions as those of the works currently underway. Table 1 below summarizes the geotechnical parameters of tested materials collected from the dams.

Table 1. Soils (core) characteristics

\begin{tabular}{lccc}
\hline Soil dam & Koudiat El Garn & Mazer & Moulay Boucheta \\
\hline Classification $($ ASTM) & Lean Clay with sand & Fat Clay & Fat Clay \\
clays $(<2 \mu \mathrm{m})((\%)$ & 14.0 & 11.8 & 19.7 \\
Silts $(2$ to $63 \mu \mathrm{m})(\%)$ & 64.4 & 75.8 & 78.8 \\
Sand $(63$ to $2000 \mu \mathrm{m})(\%)$ & 21.6 & 12.4 & 01.5 \\
Optimum Water content (\%) & 20.0 & 20.0 & 20.0 \\
D50 $(\mu \mathrm{m})$ & 18.1 & 17.1 & 05.7 \\
D90 $(\mu \mathrm{m})$ & 120.7 & 74.1 & 40.2 \\
$\mathrm{~W}_{\mathrm{L}}(\%)$ & 48.0 & 53.0 & 53.0 \\
$\mathrm{IP}(\%)$ & 23.0 & 25.0 & 32.0 \\
$\gamma_{\max }\left(\mathrm{kN} / \mathrm{m}^{3}\right)$ & 17.0 & 17.0 & 17.0 \\
\hline
\end{tabular}

\subsection{Soil dispersion assessment}

The impact of the dispersion in the design of dam core sand granular filters is not broadly defined. It was reported in the literature that dispersive soils are susceptible to suffusion; the phenomenon of dispersion is recognized when investigating soil erosion by the presence of a strong turbidity in the water. Sherard and Dunnigan [19] reported that there is not a significant difference between dispersive and non-dispersive clay. Delgado et al. [20] concluded that dispersion affects the design of granular filters. Reiffsteck [21] reported that final size of the hole in HET (Hole Erosion Test) provides the basic tool for classifying the dispersivity of the soil. To assess the susceptibility to dispersion of the base soils used, the Crumb test (ASTM D6572-00, 2000) [22] was performed. The test allowed to classify the soils according to their dispersion after more than three hours. The results are displayed on pictures showed in Fig. 3 for the three soils from the core dams, where a slight difference is to be noted in the dispersion behavior between them. No important reaction occurs between soil and water for the three tested soils. The materials disintegrate, diffuse and overflow, but no turbidity was observed around the soil samples, and they did not show any sign of disturbance leading to a suspension. They showed a similar sensitivity to water presence and at the end of the test (after 6 hours), all soil particles settled. According to ASTM D6572-00, 2000 
standard [22], these soils were then classified as of dispersion Level 1 because even with this slight disintegration they remain not-dispersive. So, the difference in plasticity index did not involve more dispersion of the less plastic soil as expected.

(a)

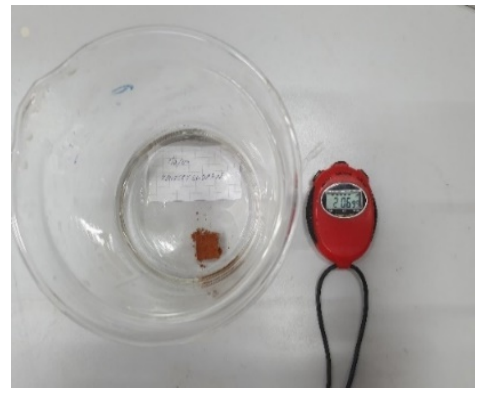

(b)

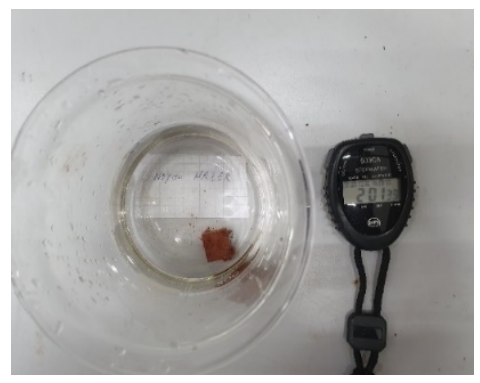

(c)

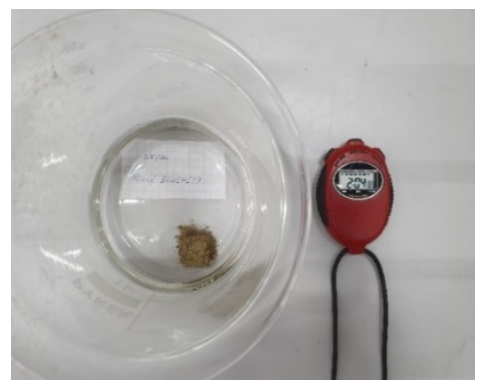

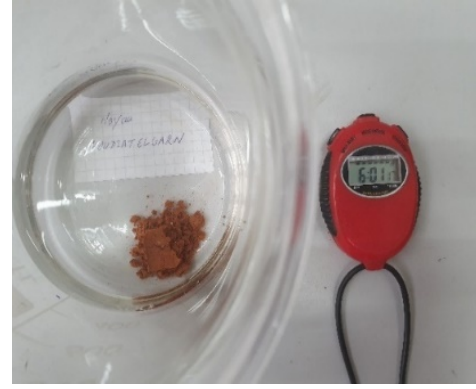
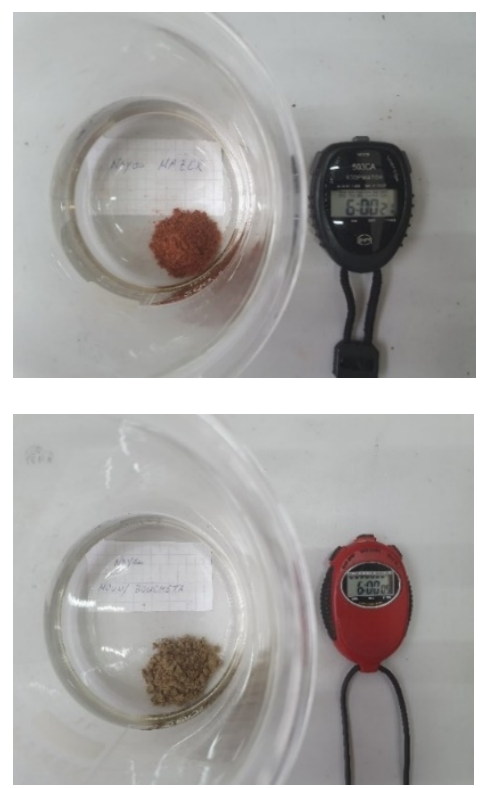

Fig. 3. Cross-section Crumb test results after $2 \mathrm{~min}$ and $6 \mathrm{~h}$ for the base soil of (a) Koudiat El Garn, (b) Mazer, and (c) Moulay Boucheta dams

\section{Experimental set up and erosion tests}

\subsection{Test apparatus}

Test device described previously $[23,24]$ involves two cylindrical Plexiglas cells, the first one (cell $N^{\circ} 1$ ) of 140 mm inner diameter and $300 \mathrm{~mm}$ of length (Fig. 4a) and the second one (cell $\mathrm{N}^{\circ} 2$ ) of $60 \mathrm{~mm}$ inner diameter and 90 mm of length (Fig. 4c), as well as a glass graduated tank, a pump, a pressure sensor at the inlet of the cell used to control applied water head to the specimen from the water supply. The soil specimen was placed in the column in a vertical position by layer compaction to reach the target density.

The first cell contains a core soil of $25 \mathrm{~mm}$ width with a predrilled hole of $15 \mathrm{~mm}$ diameter (Fig. 4b). The second cell was filled with a core soil of $50 \mathrm{~mm}$ width including a hole of $6 \mathrm{~mm}$ diameter (Fig. 4d). The upward part of the cell was filled with a glass beads layer to ensure a homogeneous spreading of the flow cross the sample section. Once saturation was achieved, the inlet pressure was increased rapidly to the target value $(100 \mathrm{kPa})$.

\subsection{Test procedure: hole erosion test}

The hole erosion tests (HET) aimed to evaluate the erodibility of dam's core material, using two seepage cells of different dimensions. Furthermore, this experimental work aimed to study the behavior of soils with regard to the initiation and progression of internal erosion, by identifying the influence of the hydraulic load, the geometric (nature and fines content) conditions, the geotechnical parameters (density, water content), and the scale effect (dimension of the test cell). In this part of the experimental program carried out, only HET performed on the core soil materials alone without downward filter are described. The principle of the HET is to establish a controlled water flow in a preformed cylindrical longitudinal pipe drilled through the specimen. The hydraulic shear stresses 
generated at the soil / water interface then cause soil erosion in the conduit. The principle of the test is to follow the diameter increase of the pipe during the test and to measure different parameters like: i) the water flow rate, ii) the pressure differential between upstream and downstream of the cell, and iii) the concentration of soil particles in the effluent.

The flow rate measurements were carried out by a digital flow meter placed upstream of the test cell (Fig. 4). The concentration of soil particles in the effluents was measured by a turbidity-meter placed at the outlet of the test cell. Therefore, through these tests, we will be able to estimate the resistance ability against erosion of the base soil and its behavior at optimum water content. Therefore, the result of analysis based on the comparison of core soil erodibility, using two different testing cells, will allow the assessment of the base soil vulnerability against erosion and to evaluate the dam sustainability. Table 2 below summarizes the test parameters and specimen characteristics which were adapted and the assessment of the vulnerability of core soils to internal erosion. So, the soil samples were tested in the same conditions.

a) $\tan$

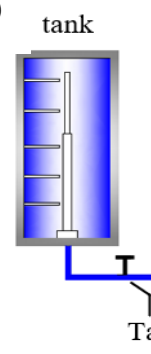

Pressure regulator
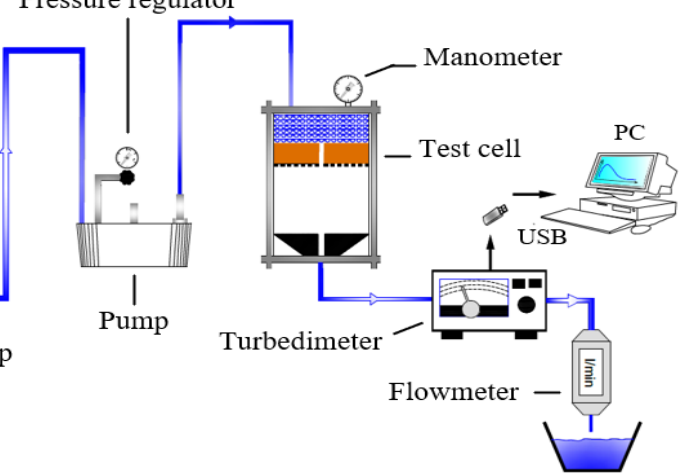

Recipient (recovered fines)

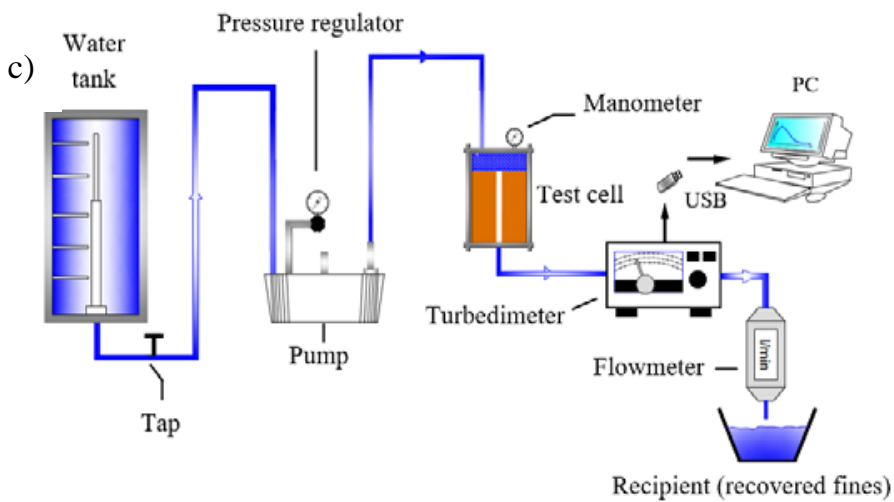

Cell N¹

b)

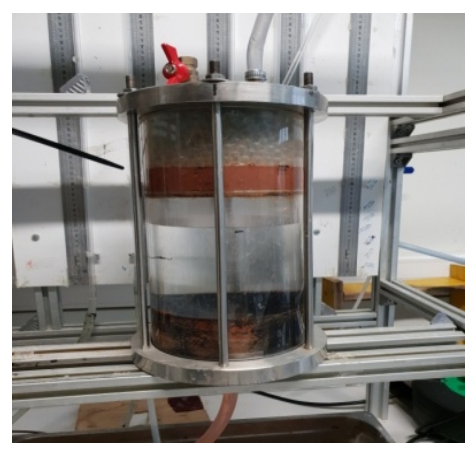

Cell $\mathrm{N}^{\circ} 2$

d)

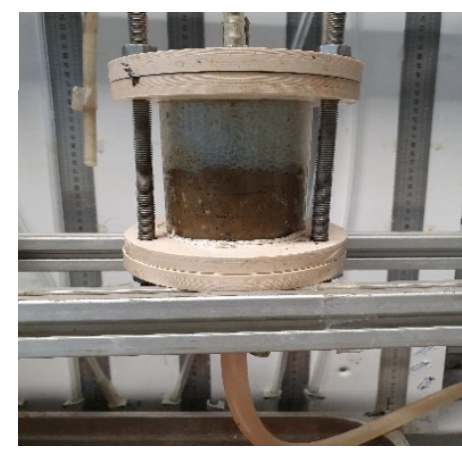

Fig. 4. View of the experimental device including (a) the cell 1 and (c) the cell 2, and the pictures of the specimen contained in (b) cell 1 and (d) cell 2

Table 2. Test parameters and specimen characteristics

\begin{tabular}{lrcc}
\hline Base soil dam & Koudiat el Garn & Mazer & Moulay Boucheta \\
\hline Water content $(\%)$ & 20 & 20 & 20 \\
Specimen dimension cell 1 (mm) & $\mathrm{L}=25$ & $\mathrm{D}=140$ \\
Specimen dimension cell 2 (mm) & $\mathrm{L}=50$ & $\mathrm{D}=60$ \\
Hole diameter $(\mathrm{mm})$ & 15 (Cell 1), 6 (Cell 2) \\
pd $\left(\mathrm{Kg} / \mathrm{m}^{3}\right)$ & \multicolumn{3}{c}{1700} \\
Applied pressures $(\mathrm{kPa})$ & \multicolumn{2}{c}{100} \\
\hline
\end{tabular}

\section{Results and discussions}

\subsection{Effect of specimen size on soil erodibility}

Using flow rate and outlet solid concentration data, the erosion kinetics was deduced as the product of particle concentration (previously correlated to turbidity measurements) and flow rate. The derived values were reported to the unit area of the hole wall. The results are reported on Fig. 5 for the three soils tested in the two cells. Overall testing time, it was clearly showed that the erosion kinetics using the cell $\mathrm{N}^{\circ} 2$ was much greater than that obtained 
in the cell $\mathrm{N}^{\circ} 1$. The recorded data from cell $\mathrm{N}^{\circ} 2$ reached a maximal value rapidly before falling to a residual value, whereas a relatively flat signal was provided from the data of the cell $\mathrm{N}^{\circ} 1$, unlike for Koudiat El Garn dam which showed the same evolution in both cells. The results clearly showed how seepage caused by a pressure lesser than $100 \mathrm{kPa}$ causes particle detachment from the hole surface. Koudiat El Garn dam seems to be very sensitive to internal erosion, mainly when using the cell $\mathrm{N}^{\circ} 2$ since the decrease of the erosion kinetics was lesser along testing time. This shows the effect of the cell dimensions on the detachment of particles and on the soil susceptibility to internal erosion. However, it has also been found that erosion susceptibility differs from one dam to another either using the cell $\mathrm{N}^{\circ} 1$ or cell $\mathrm{N}^{\circ} 2$. Koudiat El Garn dam was the least resistant in the two testing cells, owing to the large sand content making the soil less cohesive and so particles easily detachable, while Mazer dam showed the best resistance to erosion. So, even though a core dam was well designed to be resistant to erosion, using different cell dimension, it can become susceptible to erosion. The scale effect has been clearly illustrated in Fig. 5 where one can note a larger evolution of rate erosion when using cell $\mathrm{N}^{\circ} 2$ since it involves a longer hole $(50 \mathrm{~mm})$. However, the same size of the sample ( $25 \mathrm{~mm}$ thick) of the cell $\mathrm{N}^{\circ} 1$ have been used by Sherard and Dunnigan [19] for No Erosion Filter (NEF) test. But the short length of the hole did not allow the development of hydraulic load and erosion process.

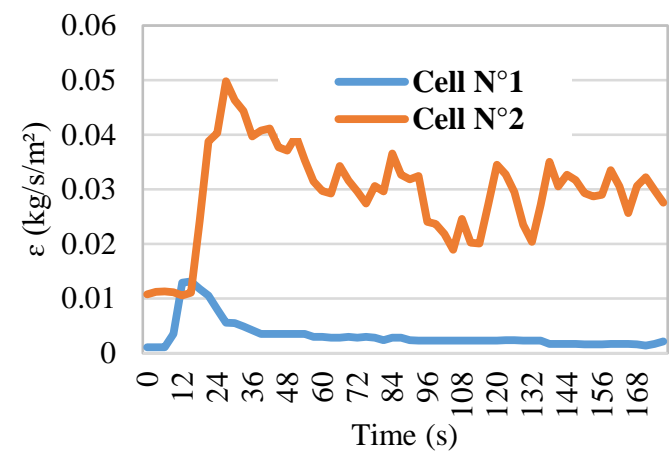

(a)

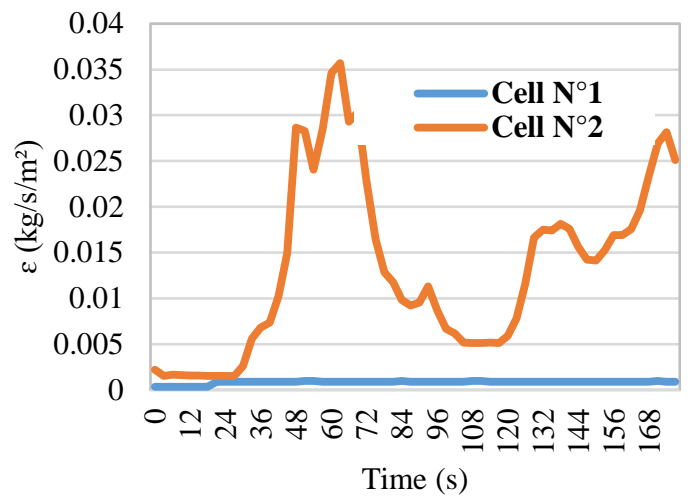

(b)

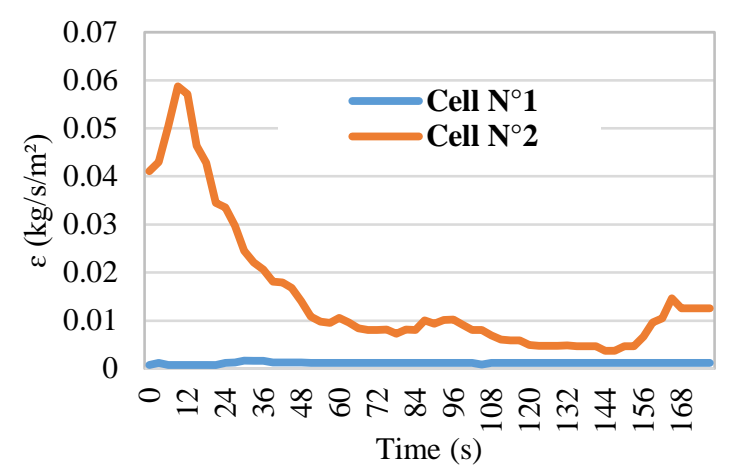

(c)

Fig. 5. View of the experimental Time evolution of erosion rate of base soil at a pressure of $100 \mathrm{kPa}$ for: (a) Koudiat El Garn, (b) Mazer and (c) Moulay Boucheta dams

\subsection{Erosion rate and soil erodibility assessment}

Using erosion data reported in the previous section, the linear erosion model according to Reddi et al. [25] provides the critical shear stress $\tau \mathrm{c}$ and the erosion coefficient Ce. The evolution of erosion rate $\varepsilon$ versus applied shear stress $\tau$ (derived from applied pressure) is showed on Figs. 6 and 7. These parameters allowed the assessment of the soil resistance to erosion and the comparison between core soils as it is summarized on Table 3 , where Ie= - $\log C_{e}$ is the erosion index, and $K_{d}=C_{e} / \rho_{d}$ is a useful coefficient for soil classification. These values which are summarized in Table 3, will be used for further classification of the three tested soils according to usual dam engineering guidelines.

The critical shear stress value $\tau_{\mathrm{c}}$ has been obtained by extrapolating the linear relation to zero erosion. The results showed that the soil from Mazer dam started to erode late (at significant hydraulic load) and its erosion rate was the weakest.

As regard to internal erosion, the above results (Table 3) can help for addressing the vulnerability to erosion of tested soils through the soil classification based on Wan and Fell [10] guidelines. Therefore, the results below (Figure 8) show that the core soil has an extremely slow erosion for all three dams by using the cell $\mathrm{N}^{\circ} 1$, since 
they fall in extremely slow erosion class. However, the soils tested in the cell $\mathrm{N}^{\circ} 2$ provided a very slow to moderately slow erosion.
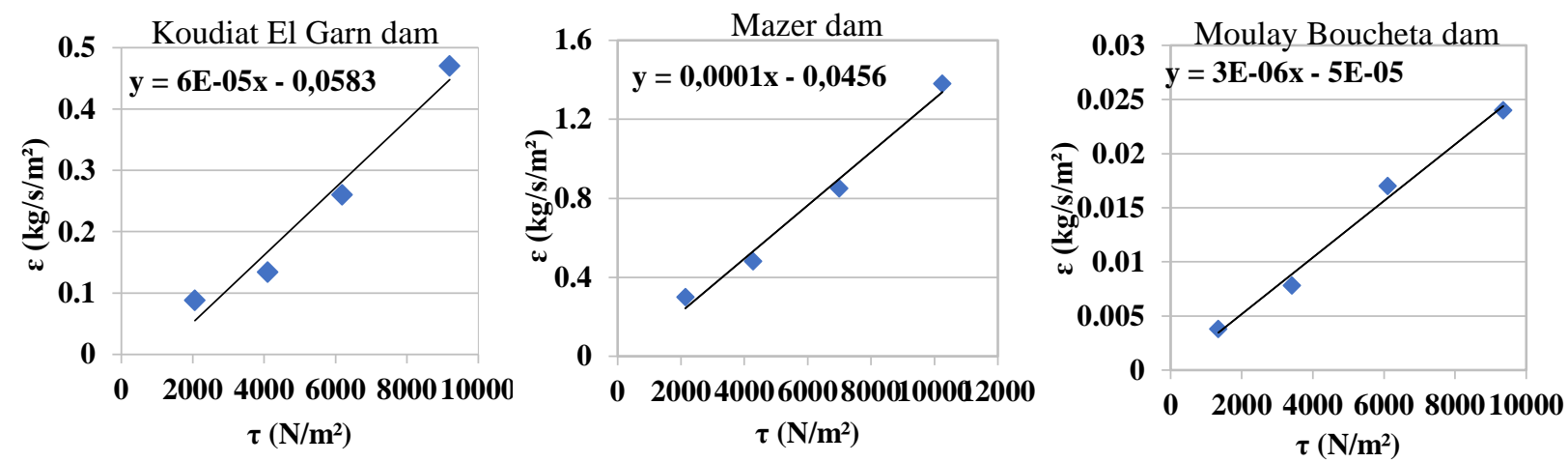

Fig. 6. Evolution of erosion rate with applied shear stress using cell $N^{\circ} 1$
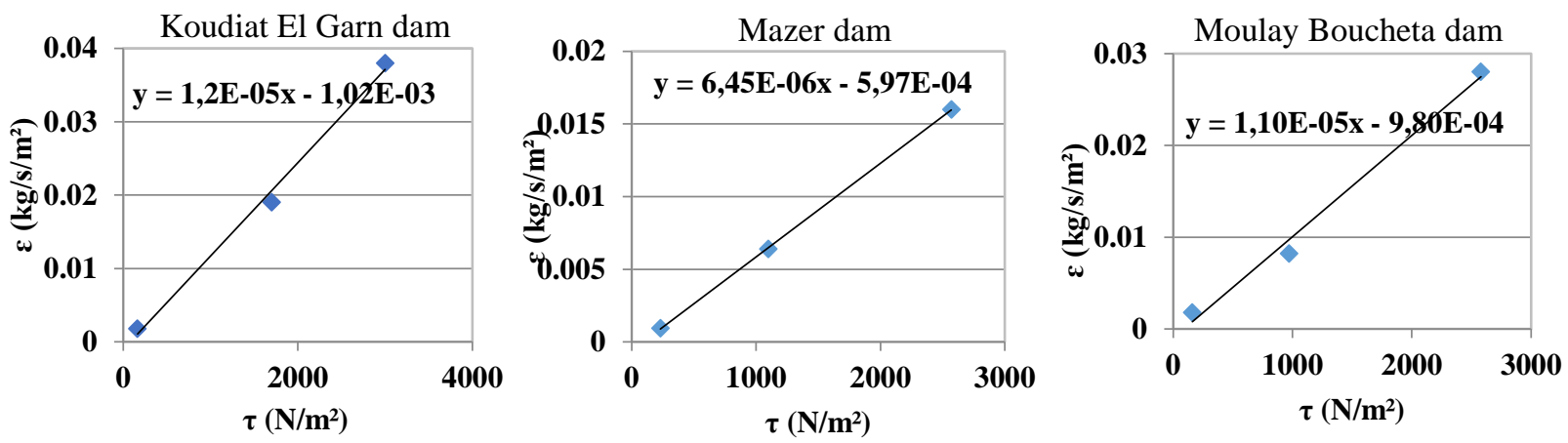

Fig. 7. Evolution of erosion rate with applied shear stress using cell $\mathrm{N}^{\circ} 2$

Table 3. Erosion parameters of tested core soils using two testing cells

\begin{tabular}{lll}
\hline Designation of cell & Cell $\mathrm{N}^{\circ} 1$ & Cell No2 \\
\hline Koudiat El Garn dam & & \\
$\tau_{c}[\mathrm{~Pa}]$ & 117 & 85 \\
$C_{e}[\mathrm{~s} / \mathrm{m}]$ & $0.6^{*} 10^{-6}$ & $1.2^{*} 10^{-5}$ \\
$I_{e}$ & 6.2 & 4.9 \\
$K_{d}\left[\mathrm{~cm}^{3} / \mathrm{N} . \mathrm{s}\right]$ & $3.5 * 10^{-4}$ & $7.0 * 10^{-3}$ \\
\hline Mazer dam & & \\
$\tau_{c}[\mathrm{~Pa}]$ & 150 & 93 \\
$C_{e}[\mathrm{~s} / \mathrm{m}]$ & $0.4 * 10^{-6}$ & $6.4 * 10^{-6}$ \\
$I_{e}$ & 6.4 & 5.2 \\
$K_{d}[\mathrm{~cm} / \mathrm{N} . \mathrm{s}]$ & $2.3^{*} 10^{-4}$ & $4.0^{*} 10^{-3}$ \\
\hline $\mathbf{M o u l a y ~ B o u c h e t a ~ d a m ~}_{\tau_{c}[\mathrm{~Pa}]}$ & 100 & \\
$C_{e}[\mathrm{~s} / \mathrm{m}]$ & $1.0^{*} 10^{-6}$ & 89 \\
$I_{e}$ & 6.0 & $1.1^{*} 10^{-5}$ \\
$K_{d}[\mathrm{~cm} / \mathrm{N} . \mathrm{s}]$ & $5.9 * 10^{-4}$ & 4.9 \\
\hline
\end{tabular}

So, even though the erosion parameters deduced from data analysis are quite different, the tested soils showed neighboring classifications as regard to erosion susceptibility, and recognized as less vulnerable to erosion (the core soil is stable) at optimum water content by using either each cell. However, the susceptibility to erosion became more greater when using the cell $\mathrm{N}^{\circ} 2$. As reported in a previous study [23, 24], the core soil from Mazer dam remains the less erodible in both cells. 
After test, the hole enlargement was evaluated in both cells for each soil and the pictures are depicted in Figs. 9 and 10. Based on the hole diameter enlargement and the cumulated eroded solid mass analysis, the results showed that core soils suffered an extremely slow erosion when using the cell $\mathrm{N}^{\circ} 1$. So, there was a slight hole enlargement (Fig. 8) of the three dams. Nevertheless, the soils from Koudiat El Garn and Moulay Boucheta dams were more sensitive to erosion when the cell $\mathrm{N}^{\circ} 2$ was used, while Mazer dam remained less sensitive to erosion, as illustrated by the hole enlargement in Fig. 10.

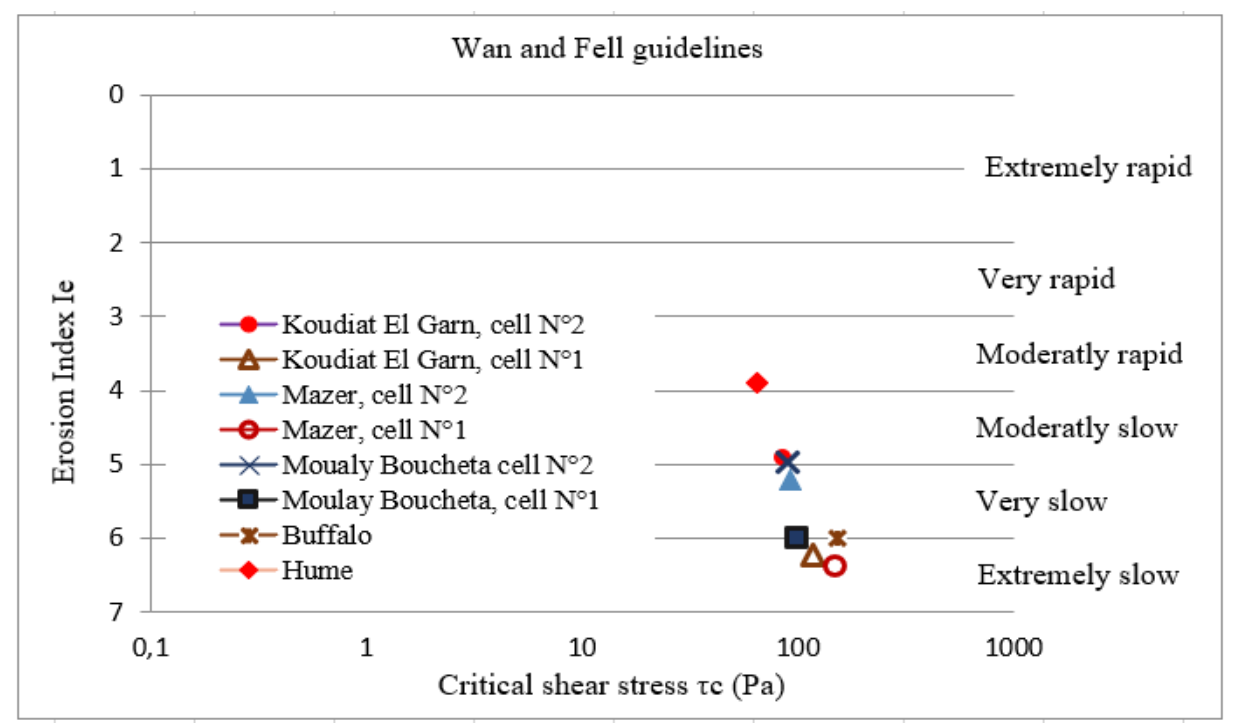

Fig. 8 Assessment of soil resistance classification according to Wan and Fell (2002) [10]
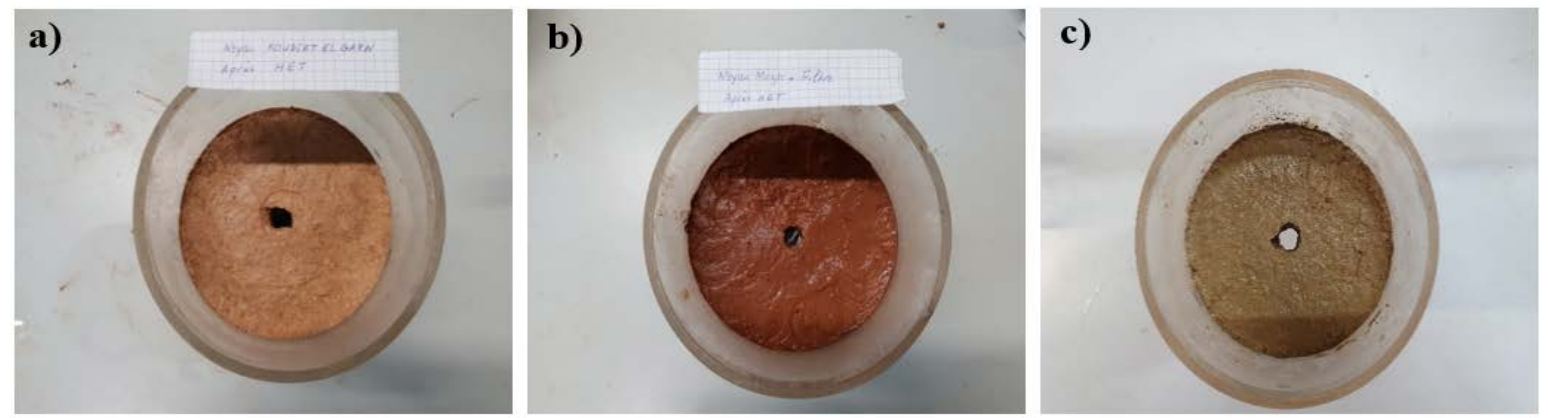

Fig. 9. Pictures of the hole after HET test of core soils using cell $\mathrm{N}^{\circ} 1$ from (a) Koudiat El Garn dam, (b) Mazer dam, and (c) Moulay Boucheta dam
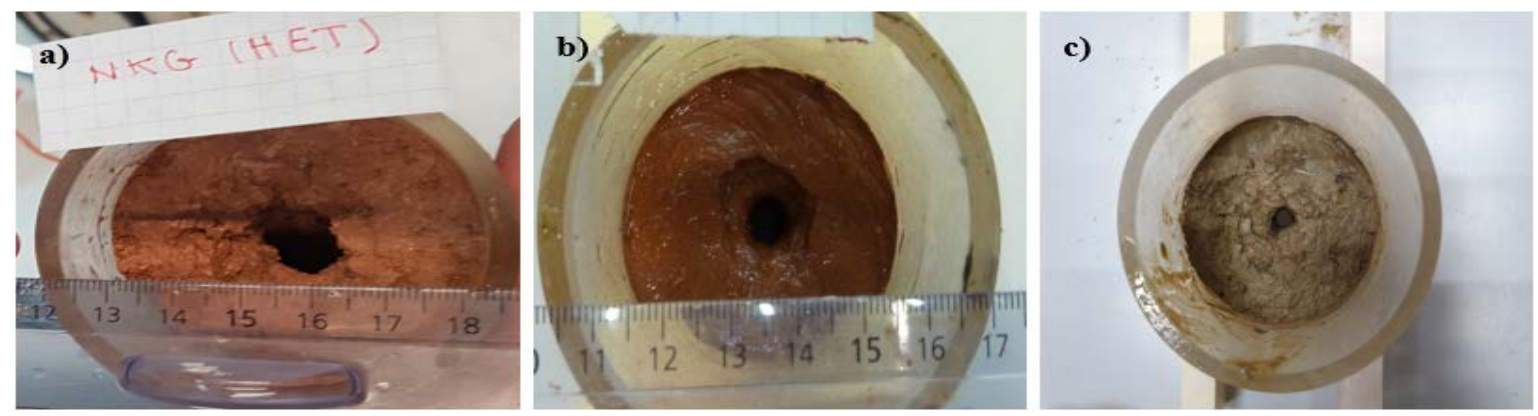

Fig. 10. Pictures of the hole after HET test of core soils using cell $N^{\circ} 1$ from (a) Koudiat El Garn dam, (b) Mazer dam, and (c) Moulay Boucheta dam

\section{Conclusion}

This study is a part of a large one investigating the susceptibility to internal erosion of three core soils collected from three dams in an area submitted to a long drought. The results from erosion tests performed on two samples (for each dam core) of different size were reported. Hole erosion test and Crumb test were carried out on core soils collected from the three dams in Morocco and aimed to assess their vulnerability to erosion. Dispersion analysis 
carried out on the core soils showed a similar sensitivity and a slight deflocculation, and then classified as nondispersive. So, the difference in plasticity index did not involve more dispersion of the less plastic soil as expected. It has been shown through the HET performed in two different sizes of seepage cell and the identification of the effectiveness of the tested core soils that they developed a high resistance to erosion even if the specimen dimensions were different in the two testing cells. Nevertheless, it has been demonstrated through changing the cell dimensions that core soil becomes slightly more or less susceptible to erosion.

Therefore, from the results of this study carried out with two different specimen thicknesses, the soil from Mazer dam started to erode late (at significant hydraulic load) and its erosion rate was the weakest. Among the comparison of different results, it appeared that, although differences are noted between erosion rate coefficient and critical shear stress values from the different testing cells, the derived erosion rate indexes from engineering guidelines were relativity close, leading to neighboring classifications. The limitation of this study is related to the number of different sample sizes (two) tested which cannot allow the deduction of any scale effect of the erosion process.

\section{References}

[1] Israr J, Indraratna B. Internal stability of granular filters understatic and cyclic loading. Journal of Geotechnical and Geoenvironmental Engineering. 2017;143(6):795-812.

[2] Skempton AW, Brogan JM. Experiments on piping in sandy gravels. Géotechnique. 1994;44(3): 449-460.

[3] Haouzi FZ, Esnault-Filet A, Courcelles B. Briefing: An experimental procedure to assess the erosional behaviour of cohesionless soils. Geotechnical Research. 2019;6(4):243-251.

[4] Fell R, Wan CF, Cyganiewicz J, Foster M. Time for development of internal erosion and piping in embankment dams. Journal of Geotechnical and Geoenvironmental Engineering. 2003;129(4):307-318.

[5] Sadaghiani SMR, Witt KJ. Experimental identification of mobile particles in suffusible non cohesive soils. European Journal of Environmental and Civil Engineering. 2011;15(8):1155-1165.

[6] Tomlinson SS, Vaid YP. Seepage forces and confining pressure effects on piping erosion. Canadian Geotechnical Journal. 2000;37(1):1-13.

[7] Gray DH, Rex RW. Formation damage in sandstones caused by clay dispersion and migration. Clays and Clay Minerals 1969;14(1):355-366.

[8] Aichison GD, Richards BG. The fundamental mechanics involved in heave and soil moisture movement and the engineering properties of soils which are important in such movement. In: Second international Research and Engineering Conference on Expansive Clay Soils. Texas A \& M Press. 1969.

[9] Sherard JL, Dunnigan LP, Decker RS. Identification and nature of dispersive soils. J. Geot. Eng. (ASCE) 1976;102(4): 287-301.

[10] Wan CF, Fell R. Investigation of internal erosion and piping of soils in embankment dams by the slot erosion test and the hole erosion test. UNICIV Rep. R-412, The Univ. of New South Wales, Sydney, Australia. 2002.

[11] Lim S. Experimental investigations of erosion in variably saturated clays. [PhD thesis report]. University of New South Wales, Australia. 2006. p.197.

[12] Benahmed N, Bonelli S. Investigating concentraded leak erosion behavior of cohesive soils by perfoming hole erosion tests. European Journal of Environmental and Civil Engineering. 2012;16(1):43-58.

[13] Wahl TA. Comparison of the hole erosion test and jet erosion test. Joint Federal Interagency Conference on Sedimentation and Hydrologic Modeling. Las Vegas. 2010.

[14] Bennabi A, Karoui T, Benamar A, Wang HQ. Some elements of comparison between two laboratory devices for soil erosion testing. ICSE10 Paris. August 2012. p.1089-1096.

[15] Haghighi I. Characterization of soil erosion and dispersion phenomena: development of tests and practical applications. [PhD thesis report]. National School of Bridges and Roads (ENPC), Paris, France. 2012.

[16] Mehenni A, Cuisinier O, Masrouri F. Impact of soil treatment on internal erosion of fine compacted soils. National Meeting of Geotechnics and Geological Engineering JNGG, Beauvais. 2014. (in French)

[17]Dyer M, Utili S, Zielinski M. The influence of desiccation fine fissuring on the stability of flood embankments. FRMRC Research Report UR11. 2007. p.64.

[18] ASTM D2487-17: Standard practice for classification of soils for engineering purposes. unified soil classification system. American Society for Testing and Materials, West Conshohocken. 2017.

[19] Sherard JL, Dunnigan LP. Filters and leakage control in embankment dams. Presented at the Seepage and Leakage from Dams and Impoundments, ASCE. 1985. p.1-30

[20] Delgado-Ramos F, Poyatos JM, Osorio F. Internal erosion of clayey soils protected by granular filters. La Houille Blanche. 2012;4-5:42-47.

[21] Reifsteck P. Evaluation of erosion of soil used in dykes and earth embankments which are subjected to flood. In: Internal Erosion of Dams and Their Foundations. Taylor \& Francis Ltd; R. Fell, J.J. Fry Eds. 2007.

[22] ASTM D6572-00: Standard test methods for determining dispersive characteristics of clayey soils by the crumb test. ASTM, West Conshohocken, PA. 2000. 
[23] Jalil A, Benamar A, Ebn Touhami M. Erosion - filtration analysis for assessing hydraulic instability of dams in Morocco and global warming effect. 2nd International Conference on EGRWSE, University of IllinoisChicago. In: Sustainable Environment and Infrastructure, Lecture Notes in Civil Engineering. Springer. 2019. p.447-454.

[24] Jalil A, Benamar A, Ebn Touhami M. Assessment of a dam vulnerability to internal erosion due to climate change in Morocco. Innovative Infrastructure Solutions. 2020;5:48.

[25] Reddi LN, Lee I-M, Bonala MVS. Comparison of internal and surface erosion using flow pump tests on a sand-kaolinite mixture. Geotechnical Testing Journal, GTJODJ. 2000;23(1):116-122.

(C) 2021 by the author(s). This work is licensed under a Creative Commons Attribution 4.0 International License (http://creativecommons.org/licenses/by/4.0/). Authors retain copyright of their work, with first publication rights granted to Tech Reviews Ltd. 